\title{
Incidência de condenações e critérios de julgamento no abate de bovinos
}

Eduarda Ângela Cesarï, Greiciele Hoffman Pessoa, Zediane Bonatto, Renan Vinicius Pastore, José Paulo Tochetto, Cezar Zanfonato, Jean Carlos Casagrande, Deise Luiza Mahl, Ângela Faccin, Daniela dos Santos de Oliveira

Instituto de Desenvolvimento Educacional do Alto Uruguai (IDEAU), Getúlio Vargas, RS, Brasil

*Autor correspondente

e-mail: eduardacesari@gmail.com

\section{Resumo}

O rebanho bovino brasileiro é o segundo maior do mundo e participa com $20 \%$ da produção de carne mundial, comercializando para mais de 180 países. Além da importância econômica, a preocupação está ligada à qualidade deste alimento, sendo de extrema relevância para o trabalho de inspeção dos produtos de origem animal desde a sanidade do rebanho aos currais de matança e à inspeção da carne, para o controle da incidência de zoonoses e outras alterações patogênicas que possam causar comprometimento à saúde pública. Desta forma, o trabalho objetivou avaliar a incidência de lesões e suas respectivas condenações em abates de bovinos na região norte do Rio Grande do Sul, através de dados fornecidos pelos serviços de inspeção locais, durante o período de 6 meses, onde foram avaliados 9.914 bovinos abatidos e inspecionados pelos sistemas de inspeção municipal e estadual. Dentre as incidências mais encontradas, o rim apresentou maior índice, com 3.679 unidades condenadas (37,10\%), seguido, respectivamente, pelo fígado (2.420; $24,40 \%)$, pulmões $(1.391 ; 14,03 \%)$, cabeça $(1.187 ; 11,97 \%)$, língua $(94 ; 0,94 \%)$ e coração $(184 ; 1,85 \%)$. No entanto, os principais casos de condena observados foram por contaminação, relacionadas ao manejo dos animais e processamento de abate. Os principais órgãos afetados foram os rins e fígado, pois exercem funções responsáveis pela transformação e excreção de substâncias tóxicas, e o pulmão, devido à aspiração de conteúdo ruminal e sangue, sendo que as alterações em órgão estão diretamente relacionadas ao manejo sanitário dos animais e ao processamento de abate, os quais devem ser melhorados para minimizar as condenações. Os órgãos acometidos com patologias e contaminação foram destinados à graxaria, bem como as duas condenações parciais de membros anteriores, e as carcaças restantes foram liberadas para consumo. 